\title{
Comparative Effect of Different Levels of Probiotics (Protexin) on Hemato-chemical Profile in Broilers
}

\author{
Ghulam Abbas 1,*, Muhammad Asif Iqbal'², Maham Riaz ${ }^{3}$, Muhammad Sajid ${ }^{4}$, Osama Zahid ${ }^{5}$, \\ Syed Wasim Abbas ${ }^{6}$, Hira Saeed ${ }^{5}$, Ali Imran Raza ${ }^{3}$, Malik Zohaib Ali $^{7}$ \\ ${ }^{1}$ Department of Animal Production, Riphah College of Veterinary Sciences, Lahore, Pakistan \\ ${ }^{2}$ Department of Parasitology, Riphah College of Veterinary Sciences, Lahore, Pakistan \\ ${ }^{3}$ Department of Clinical Medicine and Surgery, Riphah College of Veterinary Sciences, Lahore, Pakistan \\ ${ }^{4}$ Department of Anatomy, Riphah College of Veterinary Sciences, Lahore, Pakistan \\ ${ }^{5}$ Faculty of Veterinary Sciences, Riphah College of Veterinary Sciences, Lahore, Pakistan \\ ${ }^{6}$ Livestock and Dairy Development Department, Pakistan \\ ${ }^{7}$ Department of Anatomy, Faculty of Veterinary Sciences, University of Agriculture Faisalabad, Pakistan
}

Copyright $@ 2018$ by authors, all rights reserved. Authors agree that this article remains permanently open access under the terms of the Creative Commons Attribution License 4.0 International License

\begin{abstract}
The intent of the present study was to evaluate the effect of five different levels $(0,25,50,75$ or $100 \mathrm{gm} / \mathrm{ton}$ ) of probiotic (Protexin) supplemented in feed (Finisher) on blood profile of broiler chicken. Three hundred seventy five broilers (four weeks old) were randomly divided into 15 replicates having 25 birds in each replicate. These replicates were assigned to five dietary Treatments $(0,25,50,75$ or $100 \mathrm{gm} /$ ton protexin supplemented in feed) having three replicate in each treatment group. Each diet was offered to three pens of 25 broilers each. At the end of the experiment, blood samples were collected from 15 birds per treatment group. There was no mortality recorded at higher levels of probiotic in both strains. Results revealed that hematological values, serum urea, serum creatinine, serum triglycerides, serum high-density lipoprotein level, serum cholesterol level and serum low-density lipoprotein concentrations among all the groups were not affected $(\mathrm{P}>0.05)$ by treatments. However, blood hemoglobin concentration, serum glucose level and serum total protein concentration were increased significantly $(\mathrm{P}<0.05)$ in blood of birds feeding finisher ration supplemented with protexin. It was concluded that different levels of protexin in finisher ration of broiler may improve some of the blood parameters.
\end{abstract}

Keywords Protexin, Levels, Finisher Ration, Broiler, Blood Profile

\section{Introduction}

Commercial poultry farming in Pakistan is challenged with many troubles like enteric diseases and enormous losses due to contamination of feed with bacterial burden and their related pathogenic effects in birds, such as poor weight gain or even increased mortality which are major constraints in its progress [20, 21]. To overcome these problems antibiotic have been used in poultry to improve growth performance of poultry and to protect them from the antagonistic effects of pathogenic and non-pathogenic enteric microorganisms. But their usage in poultry industry has been intensively controversial due to consumers' concerns regarding food safety and antibiotic resistant bacteria in humans. As a result, use of antibacterial in poultry feed has been strictly restricted or completely banned by the European Union to avoid diseases resistance. However, several alternatives to growth-promoting antimicrobials (Herbs and herbal products, prebiotic, probiotic, enzymes, immune-modulators, microflora enhancers, organic acid and other products are investigated in recent years $[4,13,16]$. Such nutritional strategies aimed in preventing the propagation of harmful bacteria and proliferating beneficial gut microflora in order to improve the health, immune status and performance of poultry birds [14].

Probiotic are live microbial feed supplementation which plays a significant role to maintain balance in beneficial intestinal micro flora thus may stimulate performance of chick [11]. These may be single or mixed cultures of live microorganisms which confer beneficial effect on health of the host $[8,14,26]$. Probiotics include enzymes, yeast and live bacteria including various strains of Lactobacillus which are generally regarded as safe by use. Protexin is one of the commercial probiotics preparations containing a unique mixture of microorganisms, (the American Food and Drug Administration [9]. Numerous studies have shown that different levels probiotics in broiler diets may improve the performance of birds [17, 23, 25, 27]. 
However, there is scarcity of research work on the effects of probiotic on blood chemistry of birds. Hence, the aim of the present work was to investigate the effects of different levels of dietary supplementation of probiotics on blood profile of broiler chickens at their finishing stage.

\section{Materials and Methods}

Five hundred broiler (day old) were maintained at poultry shed (Pakistan). Three hundred seventy five broilers (four weeks old) were divided in to 15 replicates (25/ replicate). These replicates were further randomly allotted to five treatment groups (3 replicate/ treatment). Five diets i.e. A, B, C, D and $\mathrm{E}$ were supplemented with or without addition of Protexin (probiotic). Diet A, was without Protexin (probiotic) and served as control whereas, diets B, C, D, and E contained 0, 25, 50, 75 or $100 \mathrm{gm}$ Protexin (probiotic)/ton feed, respectively. Protexin is a commercial probiotic which is manufactured by Probiotics International Ltd. England and first time marketed in Pakistan by Hilton Pharma (Pvt.) Ltd. An analysis of the culture mix indicated a minimum presence of $2 \times 10^{9} \mathrm{cfu} / \mathrm{g}$ (Lactobacillus plantarum, Lactobacillus bulgaricus, Lactobacillus acidophilus, Lactobacillus rhamnosus, Bifidobacterium bifidum, Streptococcus thermophilus, Enterococcus faecium, Aspergillus oryzae and Candida pinpolopesi).

All the diets were iso-nitrogenous and iso-caloric and were formulated according to the nutrient requirements of broiler during finishing stage as prescribed by NRC (1994). These experimental diets were fed to the experimental birds, for two weeks (4-6 weeks of age). The experimental house was thoroughly cleaned and disinfected before the arrival of birds. All the birds were maintained under similar managemental conditions like floor space, light, temperature and relative humidity followed by accepted guidelines (FASS 2010).

At the end of last week of the experimental period, blood samples from brachial vein ( $5 \mathrm{ml}$ each) of two birds from each replicate were collected in separate screw top tubes for obtaining plasma and serum for the analysis of blood profile. Blood parameters like White blood cells (WBCs) count (X 10\% 10 ul) and red blood cells (RBCs) count (X $\left.10^{3} / \mathrm{ul}\right)$ were determined by haemocytometer method [6]. For erythrocytes sedimentation rate (ESR) determination, Westergren tube method (mm/hour) was used. Hemoglobin concentration $(\mathrm{Hb})$ was determined using Drabkin's solution by Sahli's instrument and packed cells volume (PCV) was determined using microhematocrit tubes by the method described by Coles [5].

To quantify serum glucose, cholesterol, triglycerides and high density lipoprotein (HDL) level, Enzymetic Chod-Pap method as described by Anjum [2] was used, whereas low density lipoproteins (LDL) was detected by the formula, i.e. $\left(\mathrm{T}_{\mathrm{g}} / 5+\mathrm{HDL}\right)$ - cholesterol. Total protein was assayed by biuret method and for the determination of albumin Bromocresol Green Redox Kit method was adopted whilst serum globulin was determined by deducting albumin from total protein. Urea and uric acid in the serum was estimated by Enzymatic Kinetic method described in the Redox Kit following the UV method as used by Anjum [2].

\section{Statistical Analysis}

The data were subjected to statistical analysis for interpretation of results using completely randomized design (CRD) and differences in the treatment means were compared by the Least Significance Differences [24] test.

\section{Results and Discussion}

Results of the present study revealed non-significant $(\mathrm{P}>0.05)$ effect of different levels of probiotic on hematological profile of broiler at 4-6 weeks of age (Table 1). Out of different hematological parameters determined in the present study, only hemoglobin concentration was found to be significantly affected $(\mathrm{P}<0.05)$ by treatments. Hemoglobin concentration was found to be significantly increased in birds fed diets supplemented with $100 \mathrm{gm}$ protexin /ton of feed.

Table 1. Hematological profile of broilers fed diets containing either no probiotics (control) or 25, 50, 100 or 150 gm/ton protexin

\begin{tabular}{|c|c|c|c|c|c|c|}
\hline \multirow{2}{*}{ Variables } & \multicolumn{7}{|c|}{ Treatments } & Pooled \\
& \cline { 2 - 8 } & $\begin{array}{c}\text { A } \\
\text { Control }\end{array}$ & $\begin{array}{c}\text { B } \\
\text { 25g protxin per ton feed }\end{array}$ & $\begin{array}{c}\text { C } \\
\text { 50g protxin per ton feed }\end{array}$ & $\begin{array}{c}\text { D } \\
\text { 75g protxin per ton feed }\end{array}$ & $\begin{array}{c}\text { E } \\
\text { 100g protxin per ton feed }\end{array}$ \\
\hline PCV (\%) & 26.36 & 28.10 & 27.96 & 30.03 & 27.76 & 1.45 \\
\hline ESR (mm/hour) & 2.53 & 2.30 & 2.63 & 2.66 & 2.96 & 0.393 \\
\hline $\mathrm{Hb}(\mathrm{g} / \mathrm{dl})$ & $6.167^{\mathrm{c}}$ & $6.722^{\mathrm{ab}}$ & $6.389^{\mathrm{d}}$ & $6.944^{\mathrm{a}}$ & $6.667^{\mathrm{b}}$ & 0.477 \\
\hline RBC $\left(10^{6} / \mathrm{mm}^{3}\right)$ & 2.65 & 2.77 & 2.89 & 2.85 & 2.94 & 0.16 \\
\hline WBC $\left(10^{3} / \mathrm{mm}^{3}\right)$ & 27.07 & 29.37 & 28.10 & 28.17 & 27.50 & 0.960 \\
\hline
\end{tabular}

Table 2. Serum lipids profile of broilers fed diets containing either no probiotics (control) or 25, 50, 100 or 150 gm/ton protexin 


\begin{tabular}{|c|c|c|c|c|c|c|}
\hline \multirow{2}{*}{ Variables } & \multicolumn{5}{|c|}{ Treatments } & \multirow{2}{*}{ Pooled } \\
& \cline { 2 - 7 } & $\begin{array}{c}\text { A } \\
\text { Control }\end{array}$ & $\begin{array}{c}\text { B } \\
\text { 25g protxin per ton feed }\end{array}$ & $\begin{array}{c}\text { C } \\
\text { 50g protxin per ton feed }\end{array}$ & $\begin{array}{c}\text { D } \\
\text { 75g protxin per ton feed }\end{array}$ & $\begin{array}{c}\text { E } \\
\text { 100g protxin per ton feed }\end{array}$ \\
\hline LDL (mg/dl) & 51.73 & 71.70 & 49.40 & 53.37 & 88.57 & 21.27 \\
\hline TRY (mg/dl) & 117.00 & 122.67 & 125.33 & 131.83 & 120.33 & 12.81 \\
\hline HDL (mg/dl) & 130.67 & 133.83 & 133.17 & 128.83 & 145.83 & 10 \\
\hline $\begin{array}{c}\text { Cholestrol } \\
(\mathrm{mg} / \mathrm{dl})\end{array}$ & 102.33 & 86.67 & 108.83 & 101.83 & 81.33 & 12.49 \\
\hline
\end{tabular}

Table 3. Serum metabolite profile of broilers fed diets containing either no probiotics (control) or 25, 50, 100 or 150 gm/ton protexin

\begin{tabular}{|c|c|c|c|c|c|c|}
\hline \multirow[b]{2}{*}{ Variables } & \multicolumn{5}{|c|}{ Treatments } & \multirow{2}{*}{$\begin{array}{l}\text { Pooled } \\
\text { S.D }\end{array}$} \\
\hline & \begin{tabular}{|c|} 
A \\
Control
\end{tabular} & \begin{tabular}{|c|}
$B$ \\
25g protxin per ton feed
\end{tabular} & $\begin{array}{c}C \\
50 \text { g protxin per ton feed }\end{array}$ & \begin{tabular}{|c} 
D \\
75 g protxin per ton feed
\end{tabular} & $\mid$\begin{tabular}{|c|}
$E$ \\
100 g protxin per ton feed
\end{tabular} & \\
\hline $\begin{array}{l}\text { Blood Glucose } \\
(\mathrm{mg} / \mathrm{dl})\end{array}$ & $160^{c}$ & $190.67^{\mathrm{b}}$ & $230.00^{\mathrm{a}}$ & $226.33^{\mathrm{a}}$ & $196.67^{\mathrm{ab}}$ & 19.40 \\
\hline $\begin{array}{c}\text { Total } \\
\text { protein }(\mathrm{mg} / \mathrm{dL})\end{array}$ & $4.30^{\mathrm{d}}$ & $4.70^{c}$ & $5.03^{\mathrm{b}}$ & $5.60^{\mathrm{a}}$ & $5.43^{\mathrm{ab}}$ & .198 \\
\hline Urea(mg/dL) & 134.50 & 136.17 & 145.00 & 144.17 & 150.17 & 8.18 \\
\hline $\begin{array}{l}\text { Creatinine } \\
(\mathrm{mg} / \mathrm{dL})\end{array}$ & 0.64 & 0.67 & 0.67 & 0.65 & 0.68 & 0.021 \\
\hline
\end{tabular}

Serum lipids profile data for broiler fed diets supplemented with different levels of protexin is detailed in table No.2. Statistical analysis of the data revealed non-significant $(\mathrm{P}>0.05)$ effect of different levels of probiotic on serum lipids profile of broiler at 4-6 weeks of age (Table 2). Although the differences were not statistically significant, it was noted that the high density lipoprotein (good cholesterol) increased in treated group as compared to the non-supplemented group. However, in other studies [22, 12, 19,15,17] the negative effect of probiotic supplemented diets on broiler serum cholesterol concentration documented. Some researchers $[22,12,15]$ reported a concurrent decline in serum triglyceride concentration in birds supplemented after Bacillus subtilis culture.

Effects of different levels of probiotic on some serum biochemistry parameters are presented in Table 3. Serum Glucose concentration and serum total protein concentration were increased $(\mathrm{p}<0.05)$ with increasing levels of probiotic supplementation in feed. Serum urea concentration and Serum cretinine concentration were not significantly different $(\mathrm{P}>0.05)$. Blood serum glucose and serum total protein concentrations tended to be higher $(\mathrm{P}<0.05)$ in the protexin supplemented treatments.

These effects could be explained by a higher absorptive capacity of the intestinal mucosa due to histomorphological changes [1,3] and/ or a more effective digestion of the diet due to a higher intestinal enzyme activity $[10,17,25]$, thus increasing the nutrients available to the animals.

\section{Conclusions}

Based upon the results of the present study it is concluded that a level of $75 \mathrm{~g}$ protexin per ton of feed may be recommended to stimulate blood chemistry in broiler. However, addition of probiotics in diet of broiler requires further research to clearly understand the mechanism at cellular level.

\section{REFERENCES}

[1] Aliakbarpour HR, Cha mani M, Rah imi G, Sad eghi AA and Qujeq D. 2012. The Bacillus subtilis and lactic acid bacteria probiotics influences intestinal mucin gene expression, histomorphology and growth performance inbroilers. Asian-Australas J Anim Sci 25: 1285-1293.

[2] Anjum, M. S. 2000. Productive performance and physiological behaviour of White Leghorn caged layers under different heat combating practices during summer. PhD. Thesis, Department of Poultry Science. University of Agriculture, Faisalabad.

[3] Awad WA, Gha reeb K, Abdel-Rah eem S and Böhm J. 2009. Effects of dietary inclusion of probiotic and synbiotic on growth performance, organ weights, and intestinal histomorphology of broiler chickens. Poultry Sci 88: 49-56.

[4] Bentea, M., A. Sara, L. Panta and L. Clapa. 2010. The effect of enzymatic complex allzyme SSF and organic selenium on some growth and consumption indices of broiler turkey. Anim. Sci. Biotech. 43: 9-12. 
[5] Coles, E. H. 1991. Veterinary Clinical Pathology. $4^{\text {th }}$ ed. W. B. Sanuders Company, London. pp:280-293.

[6] Despotis, G. J., A. Alsofier, C. Wltoque, T. N. Zoys, L. T. Goodnough, S. A. Santoro, K. M. Kater, P. Bames and D. G. Lappas. 1996. Evaluation of complete blood count results from a new, on site hemocytometer compared with laboratory based hemocytometer. Crit. Care Med. 24: 1163-1167.

[7] El-Baky Aaa. 2013. Clinicopathological and immunological effects of multi-strain probiotic on broiler chicken vaccinated against avian influenza virus. Global Vet 10: 534-541.

[8] FAO /WHO. 2001. Report of a joint FAO/WHO expert consultation on evaluation of health and nutritional properties of probiotics in food including powder milk with live lactic acid bacteria. Córdoba, Argentina: Food and Agriculture Organization of the United Nations and World Health Organization, 30 p.

[9] Fuller, R., (1986). Probiotics in man and animal. J. Applied Bacteriol, 66: 365-378. PMID: 2666378.

[10] Jin LZ, Ho YW, Abdullah N and Jalaludin S. 2000. Digestive and bacterial enzyme activities in broilers fed diets supplemented with Lactobacillus cultures. Poultry Sci 79: 886-891.

[11] Juven, B.J., R.J. Meinersmann and N.J. Stern. (1991). A review Antagonistic effects of Lactobacilli and Pediococci to control intestinal colonization by human enteropathogens in live poultry. J. Appl. Bacteriol., 70: 95-103.

[12] Kalavathy R, Abdullah N, Jalaludin S and Ho YW. 2003. Effects of Lactobacillus cultures on growth performance, abdominal fat deposition, serum lipids and weight of organs of broiler chickens. Br Poultry Sci 44: 139-144.

[13] Landy, N., G. G. M. Toghiani and F. F. Yazdi. 2011. Humoral immune responses of broiler chickens fed with antibiotic and neem fruit powder (Azadirachta Indica) as feed additive supplemented diet. Inter. Conf. Life Sci. Tech. 3: $153-155$

[14] Lee K, Lillehoj HS and Siragusa GR. 2010. Direct-fed microbials and their impact on the intestinal microflora and immune system of chickens. J Poultry Sci 47: 106-114.

[15] Mansoub NH. 2010. Effect of probiotic bacteria utilization on serum cholesterol and triglycerides contents and performance of broiler chickens. Global Vet 5: 184-186.

[16] Maria, T. C. 2012. Effect of supplementation of citric acid in broiler performance. M.sc Thesis Dept. of poultry science, university of agriculture Faisalabad. Pakistan.

[17] Mountzouris KC , Tsitrsikos P, Kalamara E, Nitsch S, Scha tzmayr $G$ and Fegeros K. 2007. Evaluation of the efficacy of a probiotic containing Lactobacillus, Bifidobacterium, Enterococcus, and Pediococcus strains in promoting broiler performance and modulating cecal microflora composition and metabolic activities. Poultry Science 86: 309-317.

[18] NRC. 1994. Nutrient requirements of poultry. 9th revised Ed. National Academy Press. Washington D.C. USA.

[19] Panda AK, Rao Svr, Raju MV and Sha rma SR. 2006. Dietary supplementation of Lactobacillus sporogenes on performance and serum biochemico-lipid profile of broiler chickens. J Poultry Science 43: 235-240.

[20] Patterson JA and Burkholder KM. 2003. Application of prebiotics and probiotics in poultry production. Poultry Science 82:627-631.

[21] Saima, M. Z., U. Khan, M. A. Jabbar, A. Mehmud, M. M. Abbas and A. Mehmood. 2010. Effect of lysine supplementation in low protein diets on the performance of growing broilers. Pak. Vet. J. 30: 17-20

[22] Santoso U, Tanaka K and Ohtani S. 1995. Effect of dried Bacillus subtilis culture on growth, body composition and hepatic lipogenic enzyme activity in female broiler chicks. Br J Nutr 74: 523-529.

[23] Shim YH, Shinde PL, Choi JY, Kim JS , Seo DK, Pak JI, Cha e BJ and Kwon IK . 2010. Evaluation of multimicrobial probiotics produced by submerged liquid and solid substrate fermentation methods in broilers. Asian Australas J Anim Science 23:521-529.

[24] Steel, R. G. D, J. H. Torrie and D. A. Dickey. 1997. Principles and Procedures of Statistics, a biometrical approach. $3^{\text {rd }}$ ed. McGraw Hill Book CO. Inc. New York

[25] Wang Y and Gu Q. 2010. Effect of probiotic on growth performance and digestive enzyme activity of Arbor Acres broilers. Res Vet Sci 89: 163-167.

[26] Yang Y, Iji PA and Choct M. 2009. Dietary modulation of gut microflora in broiler chickens: a review of the role of six kinds of alternatives to in-feed antibiotics. World Poultry Sci J 65: 97-114.

[27] Zakeri A and Kashefi P. 2011. The comparative effects of five growth promoters on broiler chickens humoral immunity and performance. J Anim Vet Adv 10: 1097-1101. 